\title{
Atatürk İlkeleri Türk Milletine Neler Kazandırdı?
}

\author{
Alaattin UCA \\ Karamanoğlu Mehmetbey Üniversitesi, Edebiyat Fakültesi, Tarih Bölümü, Karaman.
}

\section{Özet}

Atatürk ilkeleri Türk milletinin birlik ve beraberliğini sağlayan en önemli unsurlardan biridir. Cumhuriyetçilik, Milliyetçilik, Halkçılık, Laiklik, Devletçilik ve İnkılâpçılık olarak nitelendirilen bu kavramların hepsi Türk milletinin çimentosu ve harcıdır. Bunların her biri Türk milletinin dünyada saygın toplumlar arasında yer almasına katkıda bulunmuştur.

Atatürk ilkeleri sayesinde Türk milleti çağdaş bir toplum olmuştur. Bu ilkeler doğrultusunda yeni bir devlet kurulmuştur. Türkiye Cumhuriyeti adıyla kurulan bu devlet çağdaş, demokratik, laik ve sosyal bir hukuk devletidir.

Türkiye'de millet kendi kendini yönetmektedir. Irkçılık yoktur. Türk milleti sınıfsızdır. Dini inançlardan dolayı insanlar arasında ayrım yapılmaz. Devlet ekonomik faaliyetlere katılır ve özel sektörü de korur. Türk milleti yeniliklere açıktır. Bu ülkenin sınırları içinde yaşayan bütün insanlar hür ve eşittir.

Bunları Atatürk ilkeleri sağlamıştır.

Anahtar Kelimeler: Atatürk, Atatürk İlkeleri, Türkiye Cumhuriyeti Devleti, Türk Milleti, Millî Birlik ve Beraberlik

\section{What Atatürk Principles Brought To Turkish Nation?}

\begin{abstract}
Atatürk principles are one of the most important elements which they ensures Turkish nation's national unity and solidarity. All of the concepts known as republicanism, nationalism, populism, secularism, statism and reformism are basic building materials for Turkish Nation. Each of them contribute to Turkish Nation to settle among to respectable society in the world.

Turkish Nation succeed to be a contemporary society with help of these Atatürk principles. They established a new community according to these principles. This state's name is Republic of Turkey and this state is a contemporary, democratic, secular and social law state.

People directs themselves in Turkey. There is no racism. Turkish Nation has no class. One person doesn't exclude another person because of his or her regional thought. State supports economical events and protects private sector. Turkish people are open-minded for new ideas. All the people who live in Turkey is free and equal.
\end{abstract}

The reason of these is Atatürk principles.

Keywords: Ataturk, Ataturk Principles, Turkish Republic State, Turkish Nation, National Unity and Solidarity

\section{Giris}

Gazi Mustafa Kemal Atatürk, Türkiye Cumhuriyeti Devleti'nin kurucusudur. Osmanlı Devleti'nin y1kılması üzerine bu devleti kurmuş ve dünya kamuoyuna kabul ettirmiştir. Devlet olmak, devlet kurmak her millete nasip olmayan, dünyanın en zor işlerinden biridir.

Atatürk bu zor işi başarırken aynı zamanda Türk milletinin geri kalmışlığının nedenlerini ve bu durumdan kurtuluş imkânlarını, çağdaş uygarlık düzeyine ulaşabilmenin yollarını bulmuş, hedeflerini tespit etmiştir. İşte bu yol ve hedeflere Atatürk ilkeleri denilmektedir (Goloğlu, 1973: 9).

Atatürk ilkeleri Atatürk'ün düşünce sisteminin özüdür. Onu anlamak için ilkelerini özümsemek gerekir. "Cumhuriyetçilik" ilkesiyle Atatürk, Türk milletini cumhuriyet kavramıyla tanıştırmıştır. Daha sonra bu kavram demokrasi ile taçlanmıştır. "Milliyetçilik" ile millete kendi değerlerini tanıma ve millet olma bilinci kazandırmıştır. "Laiklik" ilkesiyle inanç ve vicdan özgürlügünü, hoşgörü anlayışını ön plana çıkarmıştır. "Halkçılık" ile sınıfsız ve imtiyazsız toplum oluşturmuş ve sosyal devlet anlayışını yerleştirmiştir. "Devletçilik" ilkesiyle devlet ve milleti bütünleştirmiştir. "İnkılâpçılık" ile millete hedef belirlemiş ve çağdaş uygarlık düzeyinin üstünü göstermiştir. Ayrıca bu ilkelerin her biriyle Atatürk hem Türk milletinin birlik ve beraberliğini sağlamıș hem de Türkiye Cumhuriyeti Devleti’ni dünyada barışa hizmet eden büyük bir devlet hâline getirmiştir.

İstanbul'un itilaf devletleri tarafından işgali üzerine iktidar millete geçmiştir (Armstrong, 1997: 94). Atatürk, millet iradesine dayalı bir devlet kurmuştur. Atatürk'ün kurduğu Türkiye Cumhuriyeti Devleti, çağdaş, demokratik laik ve sosyal bir hukuk devletidir. Bu devlet aynı zamanda modern bir devlettir (Kongar, 1981: 437, 438). Bunun böyle olmasında elbette ki Atatürk'ün rolü büyüktür. Türk milleti Atatürk ilkeleriyle, Atatürk'ün kurduğu devletin çatısı altında tek vücut haline gelmiştir.

Atatürk ilkeleri temel ve bütünleyici ilkeler olmak üzere ikiye ayrılmaktadır. Atatürk ilkelerini ve bu ilkelerin Türk milletine kazandırdıklarını şu şekilde ifade etmek mümkündür:

\section{Temel İlkeler}

Cumhuriyetçilik, Milliyetçilik, Halkçılık, Laiklik, Devletçilik ve İnkılâpçılık, Atatürk'ün temel ilkeleridir. Bu ilkelerden edindiği kazanımlarla Türk milleti ilerleme ve kendini geliştirme imkânı bulmuştur. 


\subsection{Cumhuriyetçilik}

Cumhuriyet, milletin kendi kendini yönetmesi demektir (Narter, 2004: 9). Cumhuriyetle birlikte Türk milleti bir kişinin, ailenin veya hanedanın etkisinden çıkıp kendi kendini yönetmeye başlamıştır. Millet, tebaa veya reayalıktan1 yani çok sınırlı hakkı olan, vergi veren, yönetime katılamayan, sadece tarım ve ticaretle uğraşan, emir ve buyrukların dışına çıkamayan bir topluluk olmaktan kurtulup ferdi haklara sahip vatandaş vasfını kazanmıştır (Afet İnan, 1970: 119). "İrade-i Şahane" kavramının yerini milli hâkimiyet, "Sultan idaresi" yerini de milletin kendi kendini idaresi anlamına gelen cumhuriyet kavramı almıştır (Türkdoğan, 2005: 30). Cumhuriyetle birlikte, Osmanlı İmparatorluğunun çok unsurlu sosyal yapısı ağırlıklı olarak "millî devlet" modeline uygun, Türk milletinin ağırlığının hissedildiği siyasal yapıya kavuşturulmaya gayret edilmiştir. (Genç, 2005: 97). Yani imparatorluktan ulus devlete geçilmiştir. Hanedan kavramı son bulmuştur. Milletin üstünde ne sultan, ne hakan ve ne de padişah kalmamış, devletin başı Cumhurbaşkanı olmuştur (Feyzoğlu, 1982: 55).

Türkiye'nin herhangi bir köyünde, şehrinde veya kasabasında doğan, dili, dini, etnik kökeni ne olursa olsun her vatandaş, kanunda belirtilen yaşa geldiğinde Türk milletinin teveccühünü kazanmak şartıyla, yeterli oyu almak suretiyle belirli süreler için cumhurbaşkanı, başbakan, milletvekili, belediye başkanı ya da muhtar olma hakkına kavuşmuştur. Buna seçilme hakkı denmiş, Türk milletinin bütün fertleri kanunda belirtilen yaşa geldiğinde benzer şekilde seçme hakkına da sahip olmuştur. Seçme ve seçilme hakkına verilen önem gereği, Birinci Türkiye Büyük Millet Meclisi imkânlar dâhilinde seçimle tesis edilmeye çalışılmıştır.

Cumhuriyetçilik ilkesinde, hiçbir makam, mevki ve vazife fark1 gözetilmeksizin herkesin bir oyu vardır. Bu özellik birlik ve beraberliği sağlayan önemli bir etkendir. Milletin birlik ve beraberliği eşitlik ve adaletle sağlanır. $\mathrm{Bu}$ da cumhuriyet idaresiyle mümkündür. Cumhuriyetçilik ilkesinde Türk milletinin bütün fertleri tıpkı tarağın dişleri gibi bir ve beraberdir. Vatandaş olarak herkes ülke yönetimine eşit olarak katılır.

Cumhuriyetçilikte siyasi iktidar milletin iradesine dayanır. Milletin oyunu ya da onayını almayanlar iktidar olamaz (Feyzioğlu, 1999a: 137). İktidar dil, rrk, renk, cinsiyet, siyasî düşünce, felsefî̀ inanç, din, mezhep ve benzeri sebeplerle vatandaşlar arasında ayrım yapmaz. Bir partinin tek başına iktidara gelmesi ancak toplumun büyük bir kısmını ikna etmesiyle mümkün olur. Ayrıca iktidar olan parti muhalefeti de yok saymaz. Muhalefet de iktidara meşru muhalefet eder. Böylece ikisi birden ülkeye hizmet eder.

Atatürk'e göre meclis, cumhurbaşkanı ve hükümet başkanı milletin rahatı için vardır. Onlar saltanat sürmek için değil, millete hizmet için görevlendirilmişlerdir ve millete hesap vermek durumundadirlar (Mütercim, 2008: 791).

Türk milletinin karakterine en uygun idare, cumhuriyet idaresidir. Cumhuriyetin ilanıyla birlikte artık hükümet ve millet arasında geçmişteki ayrılık kalmamıştır. (Olcaytu,

${ }^{1}$ Reaya ve tebaa kavramlarının anlamı için bkz. Ferit Devellioğlu, Osmanlıca-Türkçe Ansiklopedik Lûgat, (Yayına Hazırlayan: Aydın Sami Güneyçal), Aydın Kitabevi Yayınları, 12. Bask1, Ankara, 1995, s.880, 1045.
1998: 30). Cumhuriyetçilik çerçevesinde halka ve millete dayanan bir "halk devleti” kurulmuştur (Tanyol, 1981: 7).

Cumhuriyetin ilanıla Türkiye'de devletin demokratikleşmesi yolunda büyük bir adım atılmış ve yapılacak olan inkılâplara ortam hazırlanmıştır. Demokratik yönetim, bilimsel düşünce2, özgürlük ve her alanda tam bağımsızlık cumhuriyetçilik ilkesinin Türk milletine kazandırdığı temel kavramlardır. Cumhuriyetçilik, yeni kurulan Türkiye Cumhuriyeti'ne demokratik bir devlet olma özelliğini de kazandırmıştır (Turan, 2011: 255-258).

Cumhuriyetçilik ilkesinde, devlet yönetimi sınıfların, kişilerin, ailelerin ya da bir zümrenin eline birakılmaz. Milletin bütün bireyleri yönetimde söz sahibi olur ve merkeziyet esastır (Doğan, 2011: 310). Atatürk bu konuda şunları söylemiştir: "Efendiler, halkın kendi eliyle kendini idare etmesi ilkesini ortaya koyan bizdik. Fakat bununla, asla her ilin veya her bölgenin ayrı ayrı birer yönetim birliği kurmasını kastetmedik" (Nutuk, 1994: 327).

Cumhuriyet ilan ettikten sonra o demokrasiyle taçlandırılmak istenmiş, çok partili siyasi hayata geçmek için adımlar atılmıştır. Terakkiperver Cumhuriyet Fırkası ve Serbest Cumhuriyet Fırkasının kurulması bunun göstergesidir (Türkdoğan, 2005: 229, 230). Bu denemeler başarısız olsa da bu sürecin sonunda demokrasiye ve çok partili parlamenter rejime geçilmiştir (Erkün, 1996: 595).

Cumhuriyetçilik ilkesi Türkiye'de benimsenmiş olan yeni siyasal rejimin şeklini ve yapısını belirlemiş, kalkınmaya ve ekonomik gelişmeye imkân sağlamıştır (Vıllalta, 2000: 460).

\subsection{Milliyetçilik}

Fransız ihtilaliyle Avrupa'da ortaya çıkan milliyetçilik kavramı bir yandan bazı imparatorlukların yıkılmasına bir yandan da birçok milletin esaretten kurtulup kendi milli hâkimiyetine kavuşmasına sebep olmuştur. Almanya, İtalya, Fransa, İngiltere gibi pek çok devleti de güçlendirmiştir. Bu kavram, Osmanlı İmparatorluğunun yıkılma sebeplerinden biri olmuştur ama Türk milletini, milli hâkimiyetine ve tam bağımsızlığına kavuşturmuştur (Keskin, 1998: 299).

I. Dünya Savaşı sonunda işgallerin başladığı, ülkenin yağmalandığı, Türk milletinin yok edilmek istendiği bir dönemde milliyetçilik millete yaşama, direnme ve yeni bir devlet kurma gücünü vermiştir. Milli Mücadele, milliyetçilik ilkesinden güç alınarak başlatılmıştır (Sarıkoyuncu, 2010: 316).

$\mathrm{Bu}$ ülkenin sınırları içinde yaşayan veya yurtdışında bulunan ancak kendini Türk addeden ve Türkiye Cumhuriyeti Devleti'nin vatandaşıyım diyen herkes bu ülkenin vatandaşı anlamında Türk görülmüştür.

$\mathrm{Bu}$ anlayışa göre etnik köken itibariyle Türk, Kürt, Arnavut, Boşnak, Zaza, Gürcü, Çerkez, Pomak, Çingene, Arap, Laz, Süryani, Ermeni, Yahudi, Rum, Nasturi, Keldani, Bahai, Leh, Malakan, ya da Dürzi vs. kim olursa olsun Türkiye Cumhuriyeti Devleti'nin sınırları içinde yaşayan herkes bu ülkenin vatandaşıdır. Bu vatandaşların farklı ana dilleri olabilir. $\mathrm{Bu}$ dilleri günlük hayatlarında kullanabilirler. Ancak devletin resmî bir dili vardır, o da Türkçedir (Akgül,

\footnotetext{
${ }^{2}$ Atatürk ve bilim konusunda bkz. Aydın Sayılı, Atatürk ve Bilim, (Editör: Remzi Demir, Derleyen İnan Kalaycığulları), Atatürk Kültür Merkezi Yayını, Ankara, 2008.
} 
2006: 42; Doğan, 2011: 313). Bu ilkeyle geçmişin aksine Türk diline değer verilmiş, Türkçe, okullarda öğretilen ve her alanda kullanılan devlet dili haline gelmiştir (Hatipoğlu, 1973: 22, 23).

Atatürk'e göre Türk milletine Kürtlük, Çerkezlik ve hatta Lazlık veya Boşnaklık fikri propaganda edilmek suretiyle yapılan yanlış adlandırmalar geçmişteki keyfi idare devirlerinin mahsulüdür. Çünkü bu millet efradı da umumi Türk camiası gibi aynı müşterek maziye, tarihe, ahlâka, hukuka sahip bulunuyorlar. Yani Türk milletindendirler (Atatürk'ün Görüş ve Direktifleri, 2008: 72, 73; Türkdoğan, 2005: 159, 160).

Atatürk'ün Milliyetçilik ilkesinde rrkçılık yoktur (Sarınay, 1990: 86). Ona göre Türkiye Cumhuriyeti Devleti'nin sınırları içinde veya dışında yaşayan ancak kendini Türk hisseden herkes Türk'tür (Kuran, 1981: 11). 1924 Anayasasının 88. Maddesi şöyle düzenlenmiştir: "Türkiye ahalisine, din ve ırk farkı olmaksızın vatandaşlık itibariyle Türk denir." (Acun vd., 2009: 419). Onun için Atatürk, "Ne mutlu Türk olana!" değil, "Ne mutlu Türküm diyene!" demiştir. Türküm demekle Türk olunmayacağının bilincindedir. Burada önemli olan Türkiye Cumhuriyeti Devletinin vatandaşı olan herkesin kendini bu anlamda Türk görmesi ve hissetmesidir (Mütercimler, 2008: 1035).

Diyarbakırlı, Vanlı, Erzurumlu, Trabzonlu, İstanbullu, Trakyalı ve Makedonyalı, Atatürk'e göre hep bir milletin evlatları, hep aynı cevherin damarlarıdır (Atatürkçülük (Birinci Kitap), 1983: 74, 75; Olcaytu, 1998: 31). Bu ilkenin ırkçılıkla alâkası kesinlikle yoktur ve karıştırılmamalıdır. İstilacılık ya da yayılmacılık hedefi de bulunmamaktadır. Atatürk'e göre Türk milliyetçiliği, Türk milletinin varlığını kurtarmış, bütünlüğünü sağlamış ve korumuştur (Yavru, 1981: 108).

Türk milleti her türlü tehlikeye karşı vatan sevgisiyle birleşip bütünleşmiştir. Bu ilkeyle etnik farklılıklardan dolayı çıkması muhtemel kavgalar önlenmiş ve milletin birlik ve beraberliği sağlanmıştır. İnsanların farklı etnik kökenden gelmesi Türkiye'nin zenginliğidir. Ancak Türkiye'nin birlik ve beraberliğine kast eden, bölgecilik, bölücülük, ayrımcılık yapan, vatanla, milletle, devletle, bayrakla ya da Türkiye'nin milli ve manevi değerleriyle problemi olan her kim olursa olsun bu anlayış içinde kendine yer bulamaz (Altuğ, 1985: 210).

Milliyetçilik ilkesiyle vatan birliği, dil birliği, ırk ve soy birliği, siyasal varlıkta birlik, kültür ve tarih birliği kavramları da ön plâna çıkmaktadır (Sarınay, 1990: 51). Kültür ve tarih birliğinden kasıt, Asyatik kökenlere gitmektir. Aynı şekilde dilde birlikte kasıt doğal olarak Türkçedir. Dillerin birbirlerinden etkilenmeleri tabii olduğundan, Türk dilinin Farsça ve Arapça gibi iki farklı kültür çevresinin etkisinden soyutlanmasından ziyade baskısından kurtarılmasıdır. Soy ve köken birliği ise eskiden beri geçerliliğini koruyan yabancı soylu askeri ve sivil yönetimin Türk unsurlarına devri ve seçkin kadroların Türkleştirilmesi değil Türkleşme sürecinin başlatılmasıdır. Bu yapılmaya çalışılırken hareket noktasının tarihten ibret alınma olduğu göz ardı edilmemelidir. Zira genellemeden kaçınılmakla birlikte bazı unsurlar arasında zemini uygun bulanların Türk milletine ihanet hususunda tereddüt etmedikleri tarihî bir hakikattir. Bundan hareketle milletin aslî unsurunun hiç olmazsa ihmal edilmemesi fikri Milliyetçilik ilkesi ile milletin eşitlenmesi ve bunun hayata geçirilmesi hedeflendi. $\mathrm{Bu}$ ilke ülkenin bütün vatandaşlarının yönetim ve devlet mekanizmasında yer almasının yolunu açtı. Tarih Tezi ve Dil Teziyle toplumun kendine dönmesini ve kendini bulmasını sağladı. Milliyetçilik ilkesiyle Türk milleti milli bir kültüre erişti (Turhan, 1965: 18). Ancak, Atatürk'ün erken ölümü ulus/millî devlet anlayışının tam rayına oturmasını engelledi (Türkdoğan, 2005: 6, 12, 13, 293, 297, 298, 394, 453).

Milliyetçilik anlayışı aynı zamanda karmaşık/kozmopolit yapıdan, aşiret ve kabile hayatından çağdaş/modern topluma geçişi ve millet bilinci oluşturmayı amaç edinir (Güler, 2007: 181). Bu o dönemde bir zorunluluktur. Çünkü Araplar, İranlılar, Arnavutlar veya Boşnaklar gibi pek çok Müslüman topluluk kavmiyet özelliklerini korurken Osmanlı Devleti coğrafyaya dayalı bir vatan kavramını ve millet kimliğini, soy varlığını önemsememişti (Türkdoğan, 2005: 141, 368, 369). Türkler tarih sahnesine çıktıkları andan itibaren Büyük Hun İmparatorluğu, Batı Hun İmparatorluğu, Akhun İmparatorluğu, Göktürk İmparatorluğu, Avar İmparatorluğu, Hazar İmparatorluğu, Uygur Devleti gibi kavim adlarıyla anılan devletler kurmuştu. Ancak ilk Müslüman Türk devleti Karahanlılar'dan itibaren bu anlayış değişmiştir. Şahıs ve yer adlarıyla anılan Karahanlılar, Gazneliler, Büyük Selçuklu İmparatorluğu, Anadolu Selçuklu Devleti, Harzemşahlar Devleti, Altınordu Devleti, Timur İmparatorluğu, Babür İmparatorluğu, Osmanlı İmparatorluğu gibi devletler ve yine kişi adlarıyla anılan pek çok beylik kurulmuştur (Çeçen, 1986: 35-282). Atatürk yeni kurduğu devletin adını Türkiye Cumhuriyeti koyarak yeniden millet anlayışına dayalı devlet geleneğine dönmüştür. Türk milletini kendi adıyla anılan yeni bir devlete kavuşturmuştur.

Atatürk bu konuda şunları söylemiştir: "Cihan tarihinde bir Cengiz, bir Selçuk, bir Osman Devleti tesis eden ve bunların hepsini hadiselerle tecrübe eyleyen Türk milleti, bu defa doğrudan doğruya kendi nam ve sıfatında bir devlet tesis ederek, bütün felâketlerin karşısında, doğuştan taşıdığı kabiliyet ve kudretle yerini aldı. Millet, mukadderatını doğrudan doğruya eline aldı ve milli saltanat ve egemenliğini bir şahısta değil, bütün fertleri tarafından seçilmiş vekillerden meydana gelen bir yüce mecliste temsil etti...” (Kocatürk, 1999: 37).

Milliyetçilik ilkesine göre, Türkiye Cumhuriyeti Devleti'nin sınırları içinde yaşayan milyonlarca insan tek bir millettir. Türkiye Cumhuriyetini kuran Türk halkına Türk milleti denir (Türkdoğan, 2005: 136). Türk milleti denildiği zaman etnik anlamda bir topluluktan bahsedilmemektedir. $\mathrm{Bu}$ topraklarda yaşayan herkes bu tanımın içindedir. $\mathrm{Bu}$ milliyetçilik anlayışının esasında kültür milliyetçiliği vardır. $\mathrm{Bu}$ anlayış birleştirici ve bütünleştiricidir (Doğan, 2011: 313).Devletin sınırları içinde yaşayan herkes, hiçbir ayrım gözetmeksizin vatandaşlık bağıyla devlete bağlıdır. $O$, bölücülüğü ve ayrımcılığı reddeder (Sansar-Temizer, 2012: 204). Türk milletini birlik ve beraberlik çatısı altında birleştirir, bütünleştirir ve yüceltir (Tünay, 2004: 263). Türk milletini ırk ya da etnik köken itibariyle parçalayıp güçsüz düşürmek isteyenlere karşı koyan en büyük güç, Milliyetçilik ilkesidir (Eroğlu, 2010: 391). Atatürk bu ilkeyle milli devlet, milli iktisat, milli tarih, milli dil ve milli kültür anlayışını da geliştirmiştir (Türkdoğan, 2005: 160). 


\subsection{Halkçılık}

Halkçılık ilkesinde sınıf kavramının yeri yoktur. Toplumda sadece meslekler vardır (Türkdoğan, 2005: 152). Her meslek bir diğerine muhtaçtır. Meslekler arasında üstünlük, alçaklık yoktur. İşçinin memura, memurun esnafa, hiç kimsenin bir diğerine üstünlüğü yoktur (Atatürkçülük (Üçüncü Kitap), 1984: 42). Bütün meslek sahiplerinin sorunlarını devlet çözmek zorundadır. Her mesleğin bir saygınlığı vardır. Çünkü herkes bu milletin refahı ve kendi geçimini temin için çalışmaktadır.

Halkçılık anlayışında sosyal bölünme ve sınıflar arası mücadelenin yeri yoktur (Dumont, 1993: 127). Halkçılık ilkesiyle Türkiye'de sınıf kavgaları önlenmiş ve milletin birlik ve beraberliği sağlanmıştır. Aydın ve avam arasında eskiden görülen ayrım kalkmıştır (Eraslan, 2000: 401, 403). Uzun yıllar yalnızca küçük çiftçilerden salınan aşar vergisi kaldırılarak vergi adaleti sağlandığı gibi sınıf ayrımına da son verilmiştir (Irmak, 1981: 258).

Türk milleti birbirinden çok farklı çıkarları olan ve bu itibarla birbiriyle mücadele eden sınıflara sahip değildir. Mevcut sinıflar ya da meslekler birbirinin tamamlayıcısı niteliğindedir (Atatürkçülük (Birinci Kitap), 1983: 94, 95; Olcaytu, 1998: 32). Hiçbir kişiye, aileye, sınıfa ya da cemaate imtiyaz verilemez (Türkdoğan, 2005: 154). Türk milletini sınıf kavgalarıyla bölmek isteyenlere karşı en sağlam savunma aracı Halkçılık ilkesidir (Eroğlu, 2010: 391). Atatürk'e göre Halkçılık, kudretin, hâkimiyetin, idarenin doğrudan doğruya millete verilmesidir (Atatürk'ün Söylev ve Demeçleri, 2006: I. 102).

Halkçılık ilkesi milletin herhangi bir sınıf veya zümre tarafından sömürülmesine müsaade etmez. Kamu menfaati, kişi ya da zümre menfaatinin üzerindedir. Halkçılık anlayışı bireylerin eşitliği, sosyal adalet, sosyal güvenlik, toplumun zayıf kesimlerinin korunması ve güçlendirilmesi, adil bir gelir dağılımı anlayışına dayanır. Halkçılık ilkesine göre devletin imkânları ve kaynakları toplum kesimleri arasında eşit ve adil dağıtılmalıdır (Çelen, 2013: 4).

Millî Mücadele yıllarında Türkiye'nin hemen yanı başında büyük bir devlet olan Rusya'da Bolşevik rejimi kurulmuştur. Sosyalizme dayanan bu yönetim dini afyon saymış, özel mülkiyeti reddetmiş ve her şeyi devletleştirmiştir. Toplumda eşitlik sağlamak adına herkesi fakirlikte eşitlemiştir. Rusya'dan askerî ve ekonomik yardım alan Gazi Mustafa Kemal Paşa [Atatürk] isteseydi çok rahat bir şekilde Türkiye'de Bolşevizmi etkin kılabilirdi. Ama o buna asla yanaşmamış, Rusya ile ilişkilerin bozulması pahasına Bolşevizmi yani komünizmi reddetmiştir (Akyol, 2008: 256, 259). Halkçılık prensibi sayesinde toplumun sosyal dengesini bozmadan ülkede eşitlik sağlamış ve toplumsal gelişmenin önünü açmıştır (Doğan, 2011: 316; Türkdoğan, 2005: 202). Sosyalizm, komünizm, kapitalizm, liberalizm, nasyonalizm, faşizm gibi herhangi bir ideolojiyi Türk milletine kabul ettirmeye kalkmamıştır (Mütercimler, 2008: 9, 10).

\subsection{Laiklik}

Laiklik en basit tanımı ile din ve devlet işlerinin birbirinden ayrilması, din ve vicdan hürriyetinin sağlanmasıdır (Kinross, 1994: 454). Laiklik, resmi bir devlet dininin bulunmamasıdır. Ayrıca laiklik, devletin din ve mezhepleri ne olursa olsun millete eşit ve adil davranmasıdır
(Ertan, 2011: 252; Türkiye Cumhuriyeti'nin Temel İlkelerinden Laiklik, 1995: 6-7).

Devletin bütün vatandaşları aynı dine mensup olmaya bilir. Mesela Türkiye'de milletin büyük çoğunluğu Müslüman ise de başka dinlere inananlar da bulunmaktadır. $\mathrm{Bu}$ durumda devletin yapacağı iki şey vardır. Ya devlet işlerini ve hukuk kurallarını bütün inanç sistemlerine göre ayrı ayrı uygulamak ya da laiklikte olduğu gibi din ve devlet işlerini birbirinden ayırmaktır. Laiklik ilkesiyle ikincisi tercih edilerek din ve devlet işleri birbirinden ayrılmıştır. İnançlarına göre her topluluğa ayrı ayrı hukuk kuralları uygulamaktansa Türkiye Cumhuriyeti Devleti'nin bütün vatandaşları ya da Türk milletinin bütün fertleri laik ya da evrensel hukuka tabi tutulmuştur (Roggendorf, 2008: 431).

Laiklik ilkesine göre, Hanefi, Şafii, Maliki, Hanbeli, Şii, Caferi, Alevi, Yahudi, Ortodoks, Katolik, Protestan, Bahai, Nasturi, Süryani, Maruni, Ezidi, Keldani, Budist, Hinduist ya da Ateist kim olursa olsun hangi inanca ya da mezhebe mensup olursa olsun bu ülkenin sınırları içinde yaşayan ve kendini Türk milletinin bir ferdi olarak gören herkes Türkiye Cumhuriyeti Devleti'nin nazarında birdir ve eşittir. Hiçbir inanç sisteminin bir diğeri üzerinde etkili olmasına ya da bir diğerini yok saymasına müsaade edilmez. Yani, devlet buna izin vermez. Devlet bütün vatandaşlarına eşit uzaklıktadır ve vatandaşları arasında ayrım yapmaz. Yeni Türk Devleti'nin kurucu belgesi niteliğinde olan Lozan antlaşmasının imza sürecinde bu anlayışla hareket edilerek askeri, adli ve mali kapitülasyonlar kaldırılmış, Türk milletinin tam bağımsızlığı sağlanmıştır (Akyol, 2008: 399, 403, 409).

Laiklik yoluyla Türkiye'de dini ve dünyevi işler birbirinden ayrılmış ve toplum sorunlarının çözülmesinde akıl, bilim ve modernleşme prensipleri esas alınmıştır (Türkiye Cumhuriyeti'nin Temel İlkelerinden Laiklik, 1995: 18). Laisizmle Türk milleti akıl hürriyetine kavuşmuştur (Atay, 2012: 23). Laiklik sayesinde toplumda kadın-erkek eşitliği sağlanmış ve kadınlar bugünkü haklarını elde etmiştir (Bozkurt, 1996: 162).

Yüzyıllar boyunca Avrupa ile kıyaslandığında çok az da olsa Anadolu'da mezhep rahatsızlıkları görülmüştür. Laiklik ilkesiyle Türk milleti bundan kurtarılmaya çalışılmıştır (Feyzioğlu, 1999b: 210). Laiklik Türkiye'de mezhepler ve tarikatlar arası sürtüşme ve çatışmaları ortadan kaldıran ve Türk milletinin birliğini pekiştiren önemli bir faktördür (Olcaytu, 1998: 22). Türk milletini inanç ve mezhep farklılıklarından dolayı kavga ettirip bölmek isteyenlere karşı, millî birlik ve beraberliği sağlayan en etkili güç laikliktir (Eroğlu, 2010: 391). Böylece inançları bahane ederek Türkiye Cumhuriyeti Devleti'nin iç işlerine karışmak isteyen yabancı devletlere firsat verilmemiştir.

Laikliğin tanımında yer alan başka bir unsur da din, vicdan ve ibadet özgürlüğüdür. Din ve vicdan özgürlüğünün garantisi laikliktir (Kurtcephe, 2005: 946). Hangi inanca sahip olursa olsun inancına göre yaşayan, rahatlıkla inancının gereğini yerine getirebilen insanlar çok daha huzurludur ve böyle toplumlarda millet birlik ve beraberlik içinde yaşar.

Laik devlet herhangi bir dine mensup değildir. Fakat laiklik dinsizlik demek değildir (Nutuk, 1994: 485; Türkiye Cumhuriyeti'nin Temel İlkelerinden Laiklik, 1995: 19). Çünkü devleti yönetenlerin ve milleti meydana getiren fertlerin dini inançlarının olması gayet tabiidir. Çağdaş 
dünyada fertlerin bir inanca sahip olmalarının tabiiliği kadar devletin resmî dininin olmaması, diğer ifade ile "laik" olması da önemlidir. Çünkü laik devlet bazı Marksist veya Leninist devletler gibi dini reddetmez ya da dinsizliği telkin etmez ve din aleyhtarlığı yapmaz. Aynı zamanda laik devlet dine dayalı teokratik bir devlet de değildir (Genç, 1999: 253). Devletin bu özellikleri bütün vatandaşları birbirine bağlayıp birlik ve beraberliği güçlendirir.

Laiklik herhangi bir dinî grup, inanç sistemi, mezhep ve cemaatin siyasetle iştigal ederek partileşmesine ve bu yolla siyaset yapmasına da müsaade etmez. Din ve mezhep vicdani bir durumdur. Kimse kimseyi bu hususta etkilemez ve dine dayalı siyaset yapılmaz. Durum böyle olunca dini inançlarla siyasi maksatlar çatışmaz, toplumda inanç farklılıklarından dolayı siyasi gerginlikler yaşanmaz. Böylece milletin birlik ve beraberliği sağlanmış olur.

Başka bir ifadeyle laiklik sayesinde mezhep ve din eksenli kavgalar, huzursuzluklar, anlaşmazlıklar çıkmaz. Böylece toplumda millî birlik ve beraberlik daha da güçlenir.

Laiklik, kanun önünde eşitliğe imkân verdiği için de millî birlik ve beraberliğe katkıda bulunmuştur (Çubukçu, 1999: 114). İnanc1 ne olursa olsun Türk milletinin bütün fertleri kanunlar önünde eşittir ve herkes aynı mahkemelerde yargılanır. Evrensel hukuk kuralları işletilir. Hukukta birlik sağlanır. Bu da Türkiye Cumhuriyeti Devleti'nin sınırları içinde yaşayan herkesi hem birinci sınıf vatandaş yapar hem de birlik ve beraberliği sağlar.

Laiklik, hangi dine mensup olursa olsun din adamlarının dini kıyafetlerle ibadet haneler dışında gezmesine de izin vermez (Karal, 1945: 129). Laiklik, sahte dindarlık, din istismar1, büyücülük, üfürükçülük, muskacılık gibi kavramları da tasvip etmez. Devlet bu konuda tedbir alır ve vatandaşını korur. Laiklik, rasathanenin topa tutularak yıkıldı̆̆ı (Topdemir, 2010: 455), coğrafya derslerinde harita kullanmanın uygun olup olmadığının, tıp fakültelerinde okuyan öğrencilerin eğitiminde kadavra kullanılmasının tartışıldığ1, "dünya gâvurun ahiret Müslümanın" (Habil Adem, 2009: 12) gibi yanlış düşüncelere dayanan birtakım bağnazlıkları, ilmi hezeyanları geride bırakmış, Türk milletine tam manasıyla bilimsel özgürlük kazandırmıştır (Feyzioğlu, 1987: 18, 19).

$\mathrm{Bu}$ ilkeye göre din adamlarının atamaları, özlük haklarının temini devlet tarafından Diyanet İşleri Başkanlığı'nca sağlanır. Bunun sebebi din işlerinin devlet kontrolünden çıkıp bazı cemaat ve teşkilatların eline geçmesini önlemektir (Özbudun, 1999: 341, 342). Bu suretle devlet din istismarını önler ve vatandaşların bölünüp parçalanmasına müsaade etmez.

Laikliğin belli bir tanımının olmadığı, her ülkenin yapısına göre farklı uygulanabileceği dolayısıyla Türkiye'de de farklı şekilde uygulandığını savunan bazı düşünceler mevcuttur (Feyzioğlu, 1999b: 140). Ayrıca bir Atatürk milliyetçiliği/Türk milliyetçiliği, Atatürk devletçiliği olduğu gibi Atatürkçü laiklik veya Türkiye'ye özgü laiklik olduğu fikri de mevcuttur (Türkiye Cumhuriyeti'nin Temel İlkelerinden Laiklik, 1995: 12). Atatürk'ün laiklik anlayışında dine saygı duyulur ancak devlet ve toplum dinin tekeline bırakılmaz (Kili, 2008: 191). Büyük çoğunluğu Müslüman olan bir toplumda yaşadığının bilincinde olan Atatürk, ancak kendisinin siyasal ve toplumsal inkılâplarına engel olmaya çalışıldığı durumlarda dine karşı çıkmıştır (Kongar, 1983: 308). O, laiklik ilkesiyle, şahsi çıkarları için dini siyasete alet eden cahil din adamlarına engel olmuştur (Dilipak, 1988: 235).

Laiklik anlayışında bilimsellik, dini siyasete karıştırmamak, dinin siyasetçiler ya da softalar elinde çıkar aracı olmasını engellemek, kimseyi inancindan dolayı kınamamak, kimseyi ibadete zorlamamak, genel ahlâk ve adaba aykırı olmamak şartıyla kimsenin ibadetini engellememek, fertleri din ve diyaneti açısından eğitmek ve öğretmek gibi hususlar ön plana çıkmaktadır (Fığlalı, 1999: 224).

Atatürk bir "deist" ya da "ateist"3 değildir (Özkes, 2012: 19). Ona göre; "Din vardır ve lüzumludur.4 Dinsiz milletlerin devamına imkân yoktur. Peygamberimiz Efendimiz Hazretleri, Allah tarafindan insanlara dini gerçekleri duyurmaya memur ve elçi seçilmiştir. Din Allah ile kul arasındaki bağlılıktır” (Kayadibi, 2005: 1037, 1038; Türkdoğan, 2005: 347, 348).

Türkiye'de eğitim faaliyetleri de laiklik ilkesine göre düzenlenmiştir (Mütercimler, 2008: 13). Eğitimde laiklik ilkesi, eğitimin dini makamların etkisinden uzak tutularak, devletin denetimine alınmasını ve Milli Eğitim Bakanlığınca yürütülmesini sağlamıştır (Türkiye Cumhuriyeti'nin Temel İlkelerinden Laiklik, 1995: 21).

Laiklik konusunda bugüne kadar yaşanan sorunlar sunidir. Bu sorunların sebebi bazı kişi veya kurumların laikliği farklı zamanlarda farklı yorumlamasıdır. Aslında Atatürk, yapılması gereken en doğru işi yapmış Türk milletinin bütün fertlerini laiklik kavramı ile tanıştırmıştır.

Laiklik ilkesi doğrultusunda zamanla Türkçe ibadet ve Türkçe ezan uygulamaları gündeme gelmiş ve bu durum bazı kişiler tarafından tepkiyle karşılanmıştır. Ancak bunun dine saygısızlık değil bir milliyetçilik hareketi olduğu iddia edilmiştir (Kuran, 1981: 11; Doğanay, 2001: 21).

Özellikle Atatürk'ün vefatından sonraki dönemde, 1950'lere kadar Türkiye'de laikliğin istismar edildiği (Türkdoğan, 2005: 355), ya da başka bir ifadeyle, laiklik ilkesinin, dinsizlik ve din düşmanlığ 1 şeklinde yorumlanmaya kalkıldığg gözden uzak tutulmamalıdır. (Turhan, 1965: 42).

\subsection{Devletçilik}

Millet, devleti kurar ve devlet de milletin güvenliğini ve adaletini sağlar. İç ve dış işlerini düzene koyar. Bu işleri millet yapamaz, milletin menfaatleri doğrultusunda devletin yapması gerekir. Bu görevi yapan devlet, milletini korur ve varlığını devam ettirmesini sağlar (Atatürkçülük (Birinci Kitap), 1983: 98, 99).

Devletçilik ilkesiyle Türkiye'de devlet ve millet birleştirilmiştir, devlet-millet işbirliği sağlanmıştır. Ayrıca Türkiye'de plânlı kalkınma, teknik gelişme de bu ilkeyle gerçekleşmiştir. Devletin açtığ 1 iş yerlerinde çalışan milletin fertleri, hem kendinin hem de devletin kalkınması için

\footnotetext{
3 Deist, Allah'ın varlığına inanan fakat dini reddeden, peygamber, melek, kitap, ahiret gibi kavramlarainanmayan, ateist ise Tanrı inancını reddeden kişi anlamına gelmektedir.

4 Atatürk'ün dine bakışı hususunda bkz. Rahmi Vardı, Atatürk'ün Manevi Dünyasl, Şeyh Yahya Efendi Kültür ve Araştırma Vakfı Yayınları, İstanbul, 2006.
} 
çalıșmıştır. Devletin bütün kapıları Türk milletinin bütün fertlerine istisnasız açılmıştır.

Devletçilik sadece devletin iş yeri açması, güvenlik ve adalet işlerine veya ekonomiye müdahalesi demek değildir. Bunun dişında devlet, siyasi, askeri, sosyal ve kültürel alanlarda rol alan bir denge mekanizmasıdır. Devletçilik, modern bir millet olmak, millî kültüre kavuşmak, demokratik bir düzen içinde gelişmek, ekonomik geleceği kazanmak üzere devletin yüklenebileceği görevlerin hepsidir (Doğan, 2011: 317).

Türkiye'de devletçilik ekonomik anlamda karma ekonomi şeklinde kendini göstermiştir. $\mathrm{Bu}$ anlayışta devlet işletmeciliği ile özel teşebbüs bir arada bulunmuştur. Devlet, öncelikle özel sektörün yapamayacağı işleri yapmıştır. Sonradan mutedil devletçilik denilen bir anlayış hâkim olmuş burada da devlet özel sektörün yapabileceği işleri de yapmaya başlamış ancak özel sektörü yok sayıp engellememiştir. Devletle özel sektör arasında tatlı bir rekabet yaşanmıştır. Devletçilik anlayışında devlet ve fert birbirine karşıt değil, birbirinin tamamlayıcısıdır. Devletçilik ilkesiyle devletin ve milletin birlikte güçlenmesi sağlanmıştır.

Devletçilik anlayışı komünizmden ve liberalizmden ayrıdır. Devlet kontrolünün yanında ferdi teşebbüse de yer vermiştir (Türkdoğan, 2005: 235). Devletçilik ilkesiyle ferdin hakk1 ferde, devletin hakkı devlete verilmiştir. Fert devlet için, devlet de fert için asla feda edilmemiştir (Türkdoğan, 2005: 344). Devlet daha çok ferdin yapamayacağı işleri üstlenmiştir. Uzun bir süre, enflasyonsuz para politikaları, denk bütçe uygulamaları ve yerli kaynakların etkin kullanımı gibi yöntemler denenmiştir (Aysan, 1984: 286, 287). Böylece devlet, milleti refaha kavuşturmak, memleketi bayındır hale getirmek için ekonomik faaliyetlerle ilgilenmiştir. Ayrıca ekonomik bağımsızlık da sağlanmıştır. Devlet ve millet ekonomik faaliyetler gerçekleştirmekte özgür olmuştur (Türkdoğan, 2005: 169, 172, 185, 194, 195). Devlet, sanayileşmenin ve kalkınmanın öncülüğünü üstlenmiştir (Ülken, 1981: 35). Sanayi tesisleri memleketin içlerine, uzak yerlere yayılmıştır (Aydemir, 2011: 446). Devletçilik ilkesiyle ekonomik alanda milli gelir artmış ve milletin refah seviyesi yükselmiştir (Gök, ark., 2000: 408). Devlet bu ilkeyle hem ekonomik hem de sosyal alanda düzenleyici ve kontrol edici bir rol oynamıştır. Özel sektörün tercih etmediği ya da gücünün yetmediği durumlarda yatırım yapmış ve özel sektörü reddetmemiştir (Akdağ, 2014: 203).

Kanunlara riayet etmeleri şartıyla devletçilik ilkesinde yabanc1 sermayeye karşı çıkılmamıştır (Oral, 2006: 140; Türkdoğan, 2005: 220). Yabanciların sermayelerini kullanarak Türk milletini köleleştirmesine de müsaade edilmemiştir (Kocatürk, 1999: 310-312).

Devlet, ülkesi ve milletiyle bölünmez bir bütün olarak görülmüştür. Bu anlayıș Anayasada da yerini bulmuştur. Her alanda olduğu gibi ekonomide de devletin ve milletin yapacağı ișler vardır ve farklıdır. Devlet ve millet birbirini destekler ve uyum içinde olur. Ayrıca devlet, yatırımcıya, üreticiye, dağıtımcıya ve tüketiciye yön vermek ve gelişmeleri denetlemek durumundadır. Bütün bunlar milletin refahı ve menfaati içindir. Devletçilik ilkesiyle ekonomi planlı bir şekilde geliştirilmiştir. Ekonomik kalkınmanın belli kişilerde değil bütün millette, bölgesel değil ülkenin tümünde gerçekleşmesi hedeflenmiştir.
Devletçilik ilkesiyle iktisadi devlet teşekkülleri milli ekonominin bütün sektörleri için bir mektep vazifesi görmüştür. İşletme, muhasebe, organizasyon, işçi hakları, iş güvenliği gibi pek çok konuda devlet, özel sektöre öncü ve örnek olmuştur (Aydemir, 2011: 446).

Türkiye'de yapılan milyarlarca liralık özelleştirmeye rağmen devlet, devletçilik politikasından halâ vazgeçebilmiş değildir. Aynı şekilde aradan geçen yıllara rağmen Cumhuriyetçilikten, Milliyetçilikten, Laiklikten, Halkçılıktan ve İnkılâpçılıktan da vazgeçmek mümkün değildir.

\section{6.Ínkılâpçılık}

İnkılâpçılık, dünyada olup bitenden haberdar olmak kendini ona göre ayarlamaktır. İnkılâpçılık dünyada var olan teknolojiyi, bilimsel değerleri yakalamak ve hatta dünya seviyesinin üzerine çıkmaktır. Atatürk, inkılâpçılık ilkesiyle Türk milletini geri bırakmış müesseseleri kaldırarak toplumun ihtiyaçlarına cevap verebilen yeni müesseseler kurmuştur. Bu çağdaş ve demokratik kurumlar ve yapılan inkılâplar hem ilerlemeyi sağlamış hem de toplumun birlik ve beraberliğini pekiştirmiştir.

$\mathrm{Bu}$ ilke doğrultusunda Türkiye'de büyük değişikliklere sebep olan şu önemli inkılâplar gerçekleştirilmiştir:

- Saltanatın kaldırılması (1 Kasım 1922)

- Cumhuriyetin ilanı (29 Ekim 1923)

- Halk Firkası'nın kurulması (9 Eylül 1923)

- Ankara'nın başkent olması (13 Ekim 1923)

- Halifeliğin kaldırılması (3 Mart 1924)

- Tevhid-i Tedrisat Kanununun kabulü (3 Mart 1924)

- Şapka Kanununun kabulü/Şapka inkılâbı (25 Kasım 1925)

- Alafranga saat ve miladi takvim uygulamasına geçilmesi (26 Aralık 1925)

- Tekke, zaviye ve türbelerin kapatılması (30 Kasım 1925)

- Medeni Kanun'un kabulü (17 Şubat 1926)

- Uluslararası rakamların kabulü (20 Mayıs 1928)

- Yeni Türk Alfabesinin kabulü/Harf inkılâbı (1 Kasım 1928)

- Ağırlık ve uzunluk ölçülerinin değiştirilmesi (26 Mart 1931)

- Türk Tarihi Tetkik Cemiyetinin kurulması (12 Nisan 1931)

- Türk Dili Tetkik Cemiyetinin kurulması (12 Temmuz 1932)

- $\quad$ Soyadi Kanununun kabulü (21 Haziran 1934)

- Hafta sonu tatilinin Cuma gününden Pazar gününe alınması (1 Haziran 1935)

İnkılâpların gayesi Türkiye Cumhuriyeti milletini tamamen modern ve uygar bir toplum haline getirmektir (Olcaytu, 1998: 35). Türk milletini uygarlığın ve teknolojinin tüm imkânlarından yararlandırmaktır (Türkdoğan, 2005: 208). Uygarlık yolunda başarı, yenileşmeye bağlıdır. Sosyal hayatta, ekonomide, bilim ve fen alanında başarılı olmak da ancak yeniliklere açık olmakla mümkündür (Doğan, 2011: 321). Atatürk'e göre ink1lapların gayesi: "Türkiye Cumhuriyeti halkını tamamen asrî ve bütün mana ve eşkâliyle medeni bir heyeti içtimaiye haline îsal etmektir" (Atatürk'ün Söylev ve Demeçleri, 2006: II. 224).

İnkılâpçılık ilkesi yeniliklere açı bir millet oluşturmuştur. Sanatta gelişme de aynı yolla sağlanmıştır 
(Deligönül, 1982: 104-114). İnkılâpçılık anlayışı sayesinde Türk milleti resim, müzik, heykel, sinema, tiyatro, opera, bale gibi yeni dallarla tanışmış ve bu dallarda ilerlemeler kaydedilmiştir (Karaoğlu, 2017: 103, 104, 106, 110, 111, 112).

Atatürk, inkılâpları zamana bırakmamıştır. Çok kısa sürede ve hızla gerçekleştirmiştir (Karal, 1986: 44; Türkdoğan, 2005: 342). Atatürk'e göre, Türkiye'de doğan inkılâp güneşi yükselerek sıcaklığını yaydıkça, Türk milletinin kalbi büsbütün dünyanın büyük ve takdire layık eserlerine karşı sıcak bir sevgiyle dolmuş, bütün ilerleme prensiplerini tamamiyla benimsemiştir (Atatürk'ün Görüş ve Direktifleri, 2008: 117).

İnkılâpçılık ilkesiyle millet eski alışkanlıklarından vazgeçmiş ve sürekli bir değişim, gelişim ve yenileşme eğilimine girmiştir. $\mathrm{Bu}$ ilkeyle Türk milleti birlik ve beraberlik içinde gelişme, ilerleme ve kalkınma imkânı bulmuştur. Geri kalmış toplumlarda hep huzursuzluk vardır, kopmalar yaşanır. İnkılâpçılık sayesinde büyüyen, gelişen ve yeniliklere açık hale gelen Türk milleti birlik ve beraberliğini geliştirmiştir.

İnkılâpçılık ilkesi çağdaş, modern bir devleti öngörmektedir. Böyle bir devletin vatandaşları zengin, mutlu ve huzurlu olur. Mutlu ve huzurlu toplum bölünmez.

$\mathrm{Bu}$ günkü güçlü ve çağdaş Türkiye'nin oluşumunda inkılâpçılık ilkesinin etkisi büyüktür (Giritli, 1991: 32).

\section{Büiünleyici İlkeler}

Atatürk'ün temel ilkelerinin yanı sıra tamamlayıcı ve bütünleyici ilkeleri de vardır. Bunlar Millî Egemenlik, Millî Bağımsızlık, Millî Birlik ve Beraberlik ve Ülke Bütünlüğü, Yurtta Barış Dünyada Barış, Milli Kültür ve Çağdaşlaşma, Bilimsellik ve Akılcılık, İnsan ve İnsanlık Sevgisidir (Eroğlu, 2008: 199-205). Bu ilkelerin de temelinde Türk milletinin korunması, gelişmesi vardır.

\subsection{Millî Egemenlik}

Atatürk Samsun'a çıktığı günlerde İstanbul'da Sadaret Makamına gönderdiği 22 Mayıs 1919 tarihli raporda şöyle demiştir: "Millet yekvücut olup hâkimiyet esasını, Türklük duygusunu hedef ittihaz etmiştir." Buradaki hâkimiyetten kasıt milletin egemenliğidir. 22 Haziran 1919 tarihli Amasya Tamiminde şu temel görüşe yer vermiştir: "Milletin istiklâlini yine milletin azim ve kararı kurtaracaktır." 23 Temmuz 1919'da toplanan Erzurum Kongresinde “ Kuva-y1 Milliyeyi âmil ve irade-i milliyeyi hâkim kılmak esastır” kararı alınmıştır. Sivas Kongresinde de benzer bir karar vardır. Bunların hepsi Atatürk'ün daha yolun başında iken Milli Egemenlik fikrine dayanacağının işareti olmuştur. Aynı şekilde Sivas'ta "İrade-i Milliye", Ankara'da "Hâkimiyet-i Milliye" adlı gazetelerin çıkarılması tesadüf değildir (Feyzioğlu, 1988: 20, 21). Atatürk hayatının her döneminde yaptığı her mücadelede irâde-i milliyeye istinat ederek milletin ve vatanın muhtaç olduğu gayelere yürümüştür (Atatürk'ün Söylev ve Demeçleri, 2006: I. 65).

Milli egemenlik ilkesinin gereği olarak Türkiye'de teokratik esaslara öncelik veren bir devlet anlayışı, padişah, halife, şeyhülislam kavramları kaldırılarak yerine kayıtsız şartsız ulus egemenliğine dayalı laik bir Cumhuriyet kurulmuştur (Eliçin, 1970: 263). Cumhuriyetin birinci niteliği Atatürk'ün "Egemenlik kayıtsız şartsız milletindir" sözüne yansımıştır. Egemenliğin kaynağı millet ve milletin bu alandaki temsilcisi de Meclis olmuştur (Giritli, 1991: 38-39). Atatürk'e göre, Yeni Türkiye Devletinin yapısının ruhu milli egemenliktir. Milletin kayıtsı şartsız egemenliğidir (Atatürk'ün Görüş ve Direktifleri, 2008: 19). Bu ilke devletin kaderinde milletin söz sahibi olmasını sağlamıştır. Millet kendi geleceğini kendi belirleme hakkına ve imkânına kavuşmuştur (Turan, ark., 2011: 272, 273).

Böylece milli egemenlik kavramı Türk devlet yapısına ilk defa Atatürk sayesinde girmiş ve yerleşmiştir (Yılmaz, ark., 1998: 287). Atatürk'e göre, millete efendilik yoktur, hadimlik vardır. Bu millete hizmet eden onun efendisi olur (Atatürk'ün Söylev ve Demeçleri, 2006: I. 216).

\subsection{Millî Bağımsızlık}

Cumhuriyetin ilanıyla birlikte milli bağımsızlık da tam olarak ilan edilmiştir. Türk milletinin gelişmesini engelleyen sebeplerden biri olan kapitülasyonlar, milletin bağımsızlığına gölge düşürecek bütün sonuçlarıyla birlikte yok sayılmıştır (Şimşir, 2006: 75). Yabancı şirketler, bankalar tasfiye edilmiştir. Düyunu umumiye idaresi denilen kötü huylu kanser hücresi Türk milletinin vücudundan sökülüp atılmıştır. Azınlıklara tanınan ayrıcalık hakları kaldırılıp, bütün yurttaşlar için eşit ve tek hukuk düzeni getirilmiştir (Elçin, 1970: 263; Glasneck, 1976: 258; Tanyol, 1981: 75).

Atatürk'e göre, ne kadar zengin ve bolluk içinde olursa olsun, istiklâlden yoksun bir millet, medeni insanlık dünyası karşısında uşak olmak mevkiinden yüksek bir muameleye layık görülemez (Nutuk, 1994: 9). Bunun içindir ki "Ya istiklâl ya ölüm" parolası esas alınarak, askeri, siyasi, adli, ekonomik ve kültürel alanlar başta olmak üzere hemen her alanda Türk milletinin tam bağımsızlığı sağlanmıştır (Kocatürk, 1999: 27; Acun, ark., 2009: 434).

\subsection{Millî Birlik, Beraberlik ve Ülke Bütünlüğü}

Milli birlik ve beraberlik, Türk milletinin bir bütün olması, içinde hiçbir bölücü, ayırıcı unsura yer vermemesi demektir. Atatürk böyle bir toplum düşünmüş ve Türk gençlerinin bu duygularla eğitilmesini arzu etmiştir. Atatürk milliyetçiliğinin gereği olan milli birlik ve beraberlik ve ülke bütünlüğü aynı zamanda din ve mezhep ayrılıklarını dikkate almayan laiklik ilkesiyle de uyum sağlamıştır (Giritli, 1991: 42, 43).

Atatürk, milletin çağdaşlaşmasında hep milli birlik ve beraberliği esas almıştır. Bunu zedeleyecek hiçbir davranıştan yana olmamıştır (Goloğlu, 1973: 39). Milli birlik ve beraberlik duygusu milleti birbirine sıkıca bağlamıştır. Türk milletini oluşturan insanların doğum yerleri, eğitim düzeyleri, meslekleri, mezhepleri, siyasi görüşleri ayrı olabilir ama ay yıldızlı al bayrak birdir. Vatan, millet ve devlet birdir. Türk milletinin bütün fertleri aynı gemide yolculuk eden insanlar gibidir. Milli birlik ve beraberlik ilkesi bu geminin su almasını önlemiştir (Feyzioğlu, 1996: 51).

$\mathrm{Bu}$ ilke, Türk milletinin karşılıklı sevgi ve saygı duygusuyla birbirine bağlanmasını ve ortak amaçlara yönelik olarak varlığını devam ettirmesini sağlamıştır (Turan, ark., 2011: 275).

\subsection{Yurtta Barış Dünyada Barış}

Osmanlı Devleti yüzyıllarca fetih hareketleriyle üç kıtaya egemen olmuştur. Egemenlik alanı genişledikçe koruyuculuğu ve sorumluluğu artmıştır. Hâkimiyeti altındaki yerlere hizmet götürmüş, kapitülasyon denilen ayrıcalıklar 
tanımış, imtiyazlar vermiștir. Toplumun temel elemanlarını hep savaş alanlarında tutmuştur. Bu sebeple Türk milleti, yani temel eleman, üretim ve çalışma hayatından uzak kalmış, ekonomik gelişme sağlanamamış, bilim ve teknolojide geri kalınmıştır (Türkdoğan, 2005: 136-140). Yurtta sulh dünyada sulh anlayışı ile Türk milleti yüzyıllardır maruz kaldığı savaş yorgunluğunu üzerinden atmıştır.

Uzun yıllar süren savaşlar sonucu 17. yüzyıldan itibaren azalmaya başlayan Türk nüfus, "Yurtta sulh cihanda sulh" parolasıyla artmaya başlamıştır. Atatürk döneminde izlenen barış politikasının amaçlarından biri de nüfusun artması için gerekli ortamı oluşturmaktır (İpek, 2005: 187, 188).

Atatürk'e göre milletin hayatı tehlikeyle karşılaşmadıkça, savaştan uzak durulmalı ve barışı korumak için de savaşa hazırlıklı olunmalıdır. Asıl olan barıştır ve barışın sürekliliğidir (Atatürk'ün Söylev ve Demeçleri, 2006: I. 255; Ülken, 1981: 74). Atatürk bunu yaparken emperyalizmi reddetmiş, anlaşmazlıkların çözümünde uluslararası işbirliğine önem vermiştir. Fakat Hatay meselesinde görüldüğü gibi, Türkiye'nin haklı bir milli davası söz konusu olunca, silaha sarılmaktan çekinmemiştir (Kuran, 1981: 11).

$\mathrm{Bu}$ barışçı ve aynı zamanda gerçekçi dış politika sayesinde Türkiye, Lozan Antlaşmasından sonra BriandKellog Paktı'na katılmıştır. Yunanistan'la mübadele sorunu; Fransa'yla yabancı okullar, borçlar ve Adana-Mersin Demiryolu sorunu çözülmüştür. Türkiye, Milletler Cemiyeti'ne girmiştir. Balkan Antantı ve İngiltere ile Akdeniz Paktı imzalanmıştır. Montrö Boğazlar Sözleşmesi yapılmıştır. Sadabat Paktı gerçekleştirilmiş ve Hatay’ın Türkiye'ye katılması sağlanmıştır.

Bu ilkeyle bir taraftan Türkiye'de barış, huzur, güvenlik, istikrar sağlanırken bir taraftan da dünya barışına katkıda bulunulmuştur (Turan, ark., 2011: 276).

\subsection{Milli Kültür ve Çağdaşlaşma}

Milli kültür, Türk milletinin sahip olduğu geliştirdiği kültürdür. Bu kültürü yaşatmak ve gelecek nesillere aktarmak en önemli vazifedir. Atatürk, kültürü Türkiye Cumhuriyetinin temeli olarak görmüştür (Kocatürk, 1999: 134).

Çağdaşlaşmak; çağın gereklerine uymak, sanayileşmek, teknolojinin yeniliklerini, buluşlarını, tekniklerini kullanarak endüstri toplumu oluşturmak ve insanları bu nimetlerden yararlandırmaktır (Eroğlu, Gönülal, Arıkan, 1981: 48). Çağdaşlaşma dünya ile rekabet edebilmektir. Çağdaşlaşma sadece sanayileşmeyi değil, siyasal çağdaşlaşmayı, ekonomik büyümeyi, toplumsal değişiklikleri de sağlamıştır (Kili, 2008: 96).

Atatürk'ün çağdaşlaşma anlayışının temelinde devlet olarak tam bağımsızlık, millet olarak egemenlik, birey olarak hak ve hürriyetler yer almıştır. Çağdaşlaşma bu ortam ve bu nitelikte gerçekleştiği için değer kazanmıştır (Acun, ark., 2009: 437).

\subsection{Bilimsellik ve Akılcılık}

Atatürk, Türk milletini çağdaş uygarlık düzeyine çıkarma çabalarında hep okumayı, çalışmayı, öğrenmeyi, aklı kullanmayı ve ilim sahibi olmayı öğütlemiştir. Çünkü Atatürk, geri kalmışlığın sebebinin kültürsüzlük ve bilgisizlik olduğunu anlamıştır (Goloğlu, 1973: 15). Akla ve bilime uymayan faaliyetleri engellemiştir.
Atatürk, akılcılığa, bilim ve teknolojiye dayanarak Türk devlet hayatını, ekonomik hayatını ve bunların değerlerini, hedeflerini, toplumsal ve hukuki yapısını, yönetim esaslarını tespit etmiştir. O hep akıl ve mantık kuralları çerçevesinde hareket etmiş, bağnazlığa, hurafelere karşı çıkmıştır. O bu anlayışla çağdaş Türkiye'nin kurulmasını ve gelişmesini sağlamıştır (Acun, ark., 2009: 438). Ona göre, Türkiye'nin en mamur, en latif, en güzel yerlerini üç buçuk sene kirli ayaklarıyla çiğneyen düşmanı mağlup eden zaferin sırrı, orduların sevk ve idaresinde ilim ve fen düsturlarını rehber ittihaz etmektedir (Atatürk'ün Söylev ve Demeçleri, 2006: II. 47).

$\mathrm{Bu}$ ilke Türkiye'de aklın, mantığın gelişmesine ve bilimsel doğruların ortaya çıkmasına ve bunlara değer verilmesine sebep olmuştur (Turan, ark., 2011: 277). Türk milletinin bilimi rehber edinmesini sağlamıştır (Özçelik, Yavuz, Alpargu, 1991: 177).

\section{7.İnsan ve İnsanlık Sevgisi}

Atatürk ilkelerinin temel niteliklerinden biri de sevgi, insanlık sevgisi ve insanların birbirini sevmesidir. Ona göre, Türk milletini çağdaş uygarlık düzeyine ulaştırmanın yolu sevgiden geçer. $\mathrm{Bu}$ ancak insanları birbirine sevdirmekle olur. Atatürk, tüm insanların mutluluğu ve dünya barışı için de sevgiyi temel kabul etmiştir. O ayrıca çocuk sevgisi, toplum sevgisi, ağaç ve doğa sevgisine de önem vermiştir. Vatan sevgisi ise onda zirve yapmıştır (Goloğlu, 1973: 1113).

Bir asker olmasına rağmen onun söylediği "Millet hayatı tehlikeye uğramadıkça harp bir cinayettir" sözü insan sevgisinin göstergesidir (Sofuoğlu, 1998: 840). Aynı şekilde Atatürk döneminde Türkiye'de sağlık, eğitim, ulaştırma, sanayi alanlarında atılan adımlar da insan sevgisinin bir sonucu olmalıdır.5 O savaş meydanlarında çarpıştığı düşmanlarıyla yeri geldiğinde dost olmayı bilmiş, insanlara sevgiyle yaklaşmıştır. Onun bu düşüncesi kurduğu yeni devletin barışçı olmasını ve insana değer vermesini sağlamıştır (Erenler, 2000:124, 125; Akarsu, 1978: 31).

Atatürk'ün bütün çabası insan içindir, insana yöneliktir. Onun düşüncesinde en güçlü unsur insanlık sevgisidir. O, insanlık idealinin âşık ve seçkin simasıdır. Onun için asıl olan insanlığın mutluluğudur (Ülken, 1981: 72-75).

\section{Sonuç}

Atatürk ilkeleri Kurtuluş Savaşı yıllarında ortaya çıkmaya başlamış ve zamanla gelişme göstermiştir. Kurtuluş Savaşı yıllarında genellikle Milliyetçilik ve Halkçılık uygulanırken, cumhuriyetin ilanıyla birlikte diğer ilkeler de ihtiyaç duyuldukça devlet ve toplum hayatında yerini almıştır. Atatürk ilkeleri 1931 yılında toplanan Cumhuriyet Halk Fırkasının 3. Kurultayında partinin ilkeleri haline gelmiştir. 5 Şubat 1937 tarihinde yapılan değişiklikle bir Anayasa maddesi olmuş ve devletin temel ilkeleri niteliğine bürünmüş̧ür (Ertan, 2011: 239).

5 Bu konuda bkz. Eren Akçiçek, "Atatürk Dönemi Sağlık Kazanımları", Cumhuriyet'in Kazanımları, (Editörler: Bülent Çukurova, Fevzi Çakmak), Dokuz Eylül Üniversitesi Yayınları, İzmir, 2017, s. 315-331; Nezahat Demirhan, Cumhuriyetin Onuncu Yılının Türk Inkılâp Tarihinde Yeri ve Önemi, Atatürk Araştırma Merkezi Yayını, Ankara, 1999, s. 21-30. 
$\mathrm{Bu}$ ilkelerden Cumhuriyetçilik Türk milletinin asırlardan beri devam eden yönetim anlayışını değiştirmiştir. Devletçilik, sömürücülüğe Halkçılık yoluyla karşı koymuştur. Laiklik, milletin sömürülmesini önlemiştir. Hepsini yabancı saldırısına karşı koruyan milliyetçilik de yaşama hızını inkılâpçılıktan almıştır (Türkdoğan, 2005: 238; Kinross, 1994: 526).

$\mathrm{Bu}$ ilkeler Türk milletine bağımsız bir vatan, dünyaca tanınan bir devlet sağlamıştır (Kili, 2008: 173). Türk milletinin cebine kimlik kartlarını koymuştur. Milli çıkarları korumanın milli bir görev olduğunu hatırlatmıştır (Kürkçüoğlu, 2000: 168). Milli siyaset izlenmesiyle Türk milletinin milli sınırlar içinde kalarak ve kendi kuvvetine dayanarak, millet ve memleketin gerçek saadet ve refahını sağlaması mümkün kılınmıştır (Nutuk, 1994: 299).

Türkiye Cumhuriyeti Devleti'nin her bir vatandaşı bu ilkeler sayesinde eşit ve genel oy prensibiyle seçme ve seçilme hakkını kullanarak, ülkenin yönetiminde söz sahibi olmuştur. İstediği partiyi iktidara getirme güç ve imkânını eline almıştır. Milli egemenlik ve tam bağımsızlık gerçekleşmiştir. Türk milleti vatandaşlık vasfi kazanmıştır.

Etnik yapısı veya kökeni itibariyle hiç kimse sorgulanmamaktadır. Herkes inançlarını yaşayıp, yaşatabilmektedir. Devlet vatandaşın sorunlarını çözmek için gayret göstermektedir. Çağın şartlarına uymak için herkes özveriyle çalışmak imkânına sahiptir. Doğru, dürüst çalışanlar hem kendileri kazanmakta hem de devlete millete kazandırmaktadır.

Türk milleti bu ilkeler sayesinde birlik ve beraberliğini sağlamış, demokratik, laik bir toplum haline gelmiş ve sosyal bir hukuk devleti olma anlayışını benimsemiştir (Hughes, 1994: 147, 148). Siyaset, savunma, ekonomi, eğitim ve kültür alanlarında ihtiyaçlarını karşılayıp, gelişmesini tamamlamıştır. Atatürk ilkeleri Türk milletinin huzurunu, refahını sağladıkça, ona insanca yaşama imkânı verdikçe milletin devlete bağlılığ artmıştır.

$\mathrm{Bu}$ ilkeler Türk milletini bir arada tutmuş ve onun muasır medeniyetler seviyesine ulaşmasına yardımcı olmuş, çağdaş ve uygar dünyada saygın bir toplum haline gelmesini sağlamıştır (Gökberk, 1997: 44, 46; Sayılı, 2008: 15). Atatürk ilkeleri ırk, mezhep, cinsiyet ayrımı yapmadan herkese eşit haklar vermiştir. Türk milletinin bütün fertleri, ülkenin her yerinde ve her işinde yetenekleri ölçüsünde herhangi bir ayrım yapılmadan yer ve görev alabilmiştir.

Atatürk ilkeleriyle sınıfsız bir toplum, millete hizmet eden bir devlet anlayışı gerçekleşmiştir (Alpargu, Selvi, Şahin, 2011: 242). Halk ile devlet, ülkeyle millet bütünleşmiştir. Atatürk ilkeleriyle Türk milleti medeni bir toplum haline gelmiştir (Aydın, 2000: 250, 258).

Bu ilkeler, Türk milletine bağımsızlık, eşitlik, katılımcılık (seçme ve seçilme hakkı), millet bilinci, modernlik, özgürlük, refah kazandırmıştır. Türk milleti sahip olduğu ve olması gereken hak ve hürriyetlerini kavramıştır. Yani topluma hakları öğretilmiş ve hakkını arama hakkı tanınmıştır (Tural, 2000: 1248).

İlkeler Türk milletine bayındır, demokratik, laik, tam bağımsız bir ülke sağlamıştır. Akıl ve bilim ön plâna çıkarılmıştır. Türk milletini birleştirmiş, bütünleştirmiş ve kaynaştırmıştır. Barışçı ve insani değerleri, demokratik prensipleri ön plana çıkarmıştır. Çağdaş eğitim ve öğretimi zorunlu kılmıştır. Türk milletinin yaşam standartlarını yükseltmiştir (Özbey, 2000: 274, 276, 278, 281, 284, 288).

Türkçe, Atatürk ilkeleri sayesinde bilim, ticaret ve sanat dili haline gelmiştir (Hatipoğlu, 1973: 23, 31, 37). Türkiye adıyla yeni bir devlet kurulmuştur. Türk kavramı bir üst kimlik olarak benimsenmiştir.

Türkiye ve Türk milleti, “Avrupa'nın Hasta Adamı" olmaktan kurtulmuştur (Hasanova, 1998: 384). Sevr Antlaşmasından Lozan Antlaşmasına geçilmiş ve ondan sonra da iç ve diş politikada önemli kazanımlar elde edilmiştir. Güçlü, çağdaş ve ilerici bir devlet kurulmuştur (Akın, 1992: 216). Şekeri, çimentoyu, fayansı, pencere camını ve buna benzer birçok ürünü dışarıdan almak zorunda kalan Türk milletinin sırtına mintan, ölüsüne kefen bezi bulamadığı bir dönemden bu güne Atatürk ilkelerinin aydınlatıcı gücü getirmiştir (Balcıoğlu, 2000: 70).

Yeni kurulan Türkiye Cumhuriyeti, Atatürk ilkeleri doğrultusunda kadın erkek eşitliği, sosyal adalet, sosyal güvenlik, toplumun korunması, gelir dağılımında adalet, devlet imkânlarının millete eşit götürülmesi gibi temel kavramları benimsemiştir. Emperyalizm, kapitalizm, komünizm ve sosyalizm gibi dünyada etkin olan akımlardan uzak durmuş ve bunların baskısından kurtulmuştur (Selek, 1973: 488). İnsanlık sevgisi ve barış kavramına önem verilerek ülkede ve dünyada barışa katkıda bulunmuştur.

Atatürk ilkeleri sayesinde Türk milleti huzur bulmuştur. Fakat milletin huzurunu bozmak isteyenler halâ vardır ve Türkiye Cumhuriyeti Devleti'nin yıllardan beri karşı karşıya kaldığı terör meselesi ve milletin yaşadığı huzursuzluk büyük ölçüde diş kaynaklıdır. Bu durum devleti ve milleti bölmek, parçalamak isteyen aslında insan hakları ya da bireysel özgürlüklerle ilgisi olmayan, dış destek ve vaatlere kanarak özerklik ya da bağımsızlık hayalinden de öte Türkiye'yi parçalamak hırsıyla yanıp tutuşan Marksist-Leninist bir örgüt ve onu destekleyen Amerika başta olmak üzere bir grup yabancı ülkenin sonuçsuz çırpınışlarıdır.

Yıllardır devam eden terör ve bölücülük faaliyetlerine, ondan önceki sağ-sol çatışmalarına, zaman zaman alevlendirilmek istenen Alevi-Sünni ayrımcılığına ve hep çıkarılmaya çalışılan laik-antilaik çatışma beklenti ve kışkırtmalarına rağmen, Atatürk ilkelerinin birleştirici ve bütünleştirici gücüyle, Türk milletinin sağduyusuyla Türkiye Cumhuriyeti Devleti etrafındaki ateş çemberi içinde istikrarlı bir şekilde gelişmekte, büyümekte ve geleceğe güvenle bakmaktadır.

\section{Kaynaklar}

ACUN, Fatma, SOFUOĞLU, Adnan, YILMAZ, Mustafa, ANZERLİĞLU, Yonca, DOĞANER, Yasemin, GÖKGÖZ, Saime Selenga, KILINÇKAYA, Mehmet Derviş, ARIĞ, Ayten Sezer, ERDAŞ, Sadık, ERDAŞ, Nilgün, KOBAL, Yunus, TÜZÜN, Süleyman, YILDIRIM, Seyfi, KARAYEL, Nedret, AKTAŞ, Ayşe Önder, 2009. Atatürk ve Türk İnkılâp Tarihi, (Editör: Fatma Acun), 10. Baskı, Siyasal Yayın Dağıtım, Ankara.

AFET İNAN, Ayşe, 1970. Tarih’ten Bugün'e, Türkiye İş Bankası Yayını, Ankara.

AKARSU, Bedia, 1978. Atatürk Devrimi ve Yorumları, Türk Dil Kurumu Yayınları, İlkyaz Basımevi, Ankara. 
AKÇIÇEK, Eren, 2017. "Atatürk Dönemi Sağlık Kazanımları", Cumhuriyet'in Kazanımları, (Editörler: Bülent Çukurova, Fevzi Çakmak), Dokuz Eylül Üniversitesi Yayınları, İzmir, s. 315-331.

AKDAĞ, Ömer, 2014. Türk İnkılâp Tarihi, Konya.

AKGÜL, Ahmet, 2006. Bizim Atatürk, Bilge Karınca Yayınları, İstanbul.

AKIN, İlhan, 1992. Türk Devrimi Tarihi, 5. Baskı, Beta Yayınları, İstanbul.

AKYOL, Taha, 2008. Ama Hangi Atatürk, Doğan Kitap, 4. Bask1, İstanbul.

ALPARGU, Mehmet, SELVİ, Haluk, ŞAHIN, Enis, 2011. Atatürk İlkeleri ve İnkılâp Tarihi, Değişim Yayınları, İstanbul.

ALTUĞ, Yılmaz, 1985. Türk İnkılâp Tarihi, Üçdal Yayınları, İstanbul.

ARMSTRONG, HaroldCourtenay, 1997. Bozkurt Kemal Atatürk'ün Yaşamı, (Çeviren: Gül Çağalı Güven), Arba Yayınları, 5. Bask1, İstanbul.

ATATÜRK, Kemal, 1994. Nutuk 1919-1927, (Bugünkü Dille Yayına Hazırlayan Zeynep Korkmaz), Atatürk Araştırma Merkezi Yayını, Türk Tarih Kurumu Basımevi, Ankara.

Atatürkçülük (Birinci Kitap) Atatürk'ün Görüş ve Direktifleri, 1983. Genelkurmay Basımevi, Ankara.

Atatürkçülük (Üçüncü Kitap) Atatürkçü Düşünce Sistemi,1984. Milli Eğitim Basımevi, İstanbul.

Atatürk'ün Görüş ve Direktifleri, 2008. (Hazırlayan: Genelkurmay Başkanlığı), Türkiye Tekstil Sanayi İşverenleri Sendikası Kültür Yayını, İstanbul.

Atatürk'ün Söylev ve Demeçleri, 2006. Atatürk Araştırma Merkezi Yayını, Baskı: Divan Yayıncılık, C. I, II, III.

ATAY, Falih Rıfkı, 2012. Atatürkçülük Nedir?,Pozitif Yayınları, 6. Baskı, İstanbul.

AYDEMİR, Şevket Süreyya, 2011. İkinci Adam 18841938, Remzi Kitabevi, 14. Bask1, C.1, İstanbul.

AYDIN, Nurettin, 2000. "Türkiye Cumhuriyeti Devleti'nde Çağdaşlaşma Yolunda Atatürk İlke Ve İnkılâplarının Yeri Ve Önemi”, Atatürk Haftası Armağanı 10 Kasım 2000, ATASE Yayınları, Genelkurmay Basım Evi, Ankara, s. 247-265.

AYSAN, Mustafa, 1984. “Atatürk’ün Ekonomik Kalkınma Modeli”, Atatürkçülük (İkinci Kitap) Atatürk ve Atatürkçülüğe İlişkin Makaleler,Milli Eğitim Basımevi, İstanbul, s. 281-299.

BALCIOĞLU, Mustafa, 2000. "Atatürkçü Çağdaşlaşmanın Önündeki Engeller”, Atatürk Konferansları (1998-75.Yı1-Yurtiçi, Atatürk Araştırma Merkezi Yayını, Ankara, s. 67-71.

BOZKURT, Gülnihal, 1996. "Cumhuriyet Öncesi ve Sonrasında Türk Kadınının Hukuki Durumu”, Kastamonu’da İlk Kadın Mitingi'nin 75. Yıldönümü Uluslararası Sempozyumu Kastamonu 10-11 Aralık 1994, Atatürk Araştırma Merkezi Yayını, Ankara, s. 157-164.

ÇEÇEN, Anıl, 1986. Türk Devletleri, İnkılâp Kitabevi, 1. Baskı, İstanbul.
ÇELEN, Gülru, 2013. Atatürk'ün Düşünce Dünyasında Halkın Yeri, ATASE Yayınları, Ankara.

ÇUBUKÇU, İbrahim Agâh, 1999. "Halifelik, Din ve Laiklik", Atatürk Düşüncesinde Din ve Laiklik, (Yayına Hazırlayanlar: Ethem Ruhi Fığlalı-Taha Müftüoğlu-İdris Karakuş), Atatürk Araştırma Merkezi Yayını, Ankara, s.109114.

DELİGÖNÜL, Mehmet, 1982. Atatürk’ten Seçki, Türk Dil Kurumu Yayınları, Ankara.

DEMIRHAN, Nezahat, 1999. Cumhuriyetin Onuncu Yılının Türk İnkılâp Tarihinde Yeri ve Önemi, Atatürk Araştırma Merkezi Yayını, Ankara.

DEVELLİOĞLU, Ferit, 1995. Osmanlıca-Türkçe Ansiklopedik Lûgat, (Yayına Hazırlayan: Aydın Sami Güneyçal), Aydın Kitabevi Yayınları, 12. Baskı, Ankara.

DİLİPAK, Abdurrahman, 1988. Bir Başka Açıdan Kemalizm, Beyan Yayınları, 3. Baskı, İstanbul.

DOĞAN, Orhan, 2011. Atatürk İlkeleri ve İnk1lâp Tarihi XIX.-XX. Yüzyıl Türkiye Tarihi, Okutman Yayıncılık, 3. Bask1, Ankara.

DOĞANAY, Rahmi, 2001. "Saltanat'tan Cumhuriyet'e İmparatorluk'tan Milli Devlet'e", Atatürk Araştırma Merkezi Dergisi, C. 17, S. 49, s. 1-21.

DUMONT, Paul, 1993. Mustafa Kemal, (Çeviren: Zeki Çelikkol), Türk Tarih Kurumu Basımevi, Ankara.

ELİÇİN, Emin Türk, 1970. Kemalist Devrim İdeolojisi, Ant Yayınları, İstanbul.

ERASLAN, Cezmi, 2000. “Atatürk'ün Halkçılık Anlayışı ve XXI. Yüzyıl İçin Önemi”, Atatürk 4.Uluslararası Kongresi 25-29 Ekim 1999, Türkistan-Kazakistan, Atatürk Araştırma Merkezi Yayını, Ankara, C. 1, s. 393-408.

ERENLER, Ali Osman, 2000. “Atatürk'ün İnsan Sevgisi ve Dünya Barışı", Atatürk 4.Uluslararası Kongresi 25-29 Ekim 1999, Türkistan-Kazakistan, Atatürk Araştırma Merkezi Yayını, Ankara, C. 1, s. 123-137.

ERKÜN, Sefa, 1996. “Toplumsal Değişmelerin Işı̆̆ında Atatürk İlkeleri ve Belirgin Özellikleri”, Uluslararası İkinci Atatürk Sempozyumu 9-11 Eylül, 1991-Ankara, Atatürk Araştırma Merkezi Yayını, Ankara, C. 1, s. 589-614.

EROĞLU, Hamza, 2008. Atatürk Hayatı ve Üstün Kişiliği, Savaş Yayınevi, Ankara.

2010. Türk İnkılâp Tarihi, Savaş

Yayınevi, 4. Baskı, Ankara.

EROĞLU, Hamza, GÖNÜLAL, İsmet, ARIKAN, Muzaffer, 1981. Atatürk ve Türk Toplumu, Türkiye Zirai Donatım Kurumu Yayını, Ankara.

ERTAN, Temuçin Faik, 2011. "Atatürk İlkeleri”, Başlangıcından Günümüze Türkiye Cumhuriyeti Tarihi, (Editör: Temuçin Faik Ertan), Siyasal Kitabevi, Ankara.

FEYZİĞLLU, Turhan, 1987. "Atatürk Yolu: Akılc1, Bilimci, Gerçekçi Yol”, Atatürk Yolu, (Hazırlayanlar: Turhan Feyzioğlu, Mustafa Aysan, Hamza Eroğlu, İsmet Giritli, Mehmet Gönlübol), Atatürk Araştırma Merkezi Yayını, 2. Bask1, Ankara, s. 3-65. 
1988. Türk Milli Mücadelesinin ve Atatürkçülüğün Temel İlkelerinden Biri Olarak Millet Egemenliği, Atatürk Araştırma Merkezi Yayını, Türk Tarih Kurumu Basımevi, Ankara.

1996. Atatürk ve Milliyetçilik, Atatürk Araştırma Merkezi Yayını, Türk Tarih Kurumu Basımevi, 3. Baskı, Ankara.

1999a. "Türk İnkılâbının Temel Taşı: Laiklik”,Atatürk Düşüncesinde Din ve Laiklik, (Yayına Hazırlayanlar: Ethem Ruhi Fığlalı-Taha Müftüoğlu-İdris Karakuş), Atatürk Araştırma Merkezi Yayını, Ankara, s.137198.

1999b. "Irmaklar Tersine Akıtılamaz",Atatürk Düşüncesinde Din ve Laiklik, (Yayına Hazırlayanlar: Ethem Ruhi Fığlalı-Taha Müftüoğlu-İdris Karakuş), Atatürk Araştırma Merkezi Yayını, Ankara, s.199212.

FEYZOĞLU, Osman Güngör, 1982. Atatürk İlkeleri ve İnkılâbımız, Milli Eğitim Basımevi, İstanbul.

FIĞLALI, Ethem Ruhi, 1999. "İslâm ve Laiklik”,Atatürk Düşüncesinde Din ve Laiklik, (Yayına Hazırlayanlar: Ethem Ruhi Fiğlalı-Taha Müftüoğlu-İdris Karakuş), Atatürk Araştırma Merkezi Yayını, Ankara, s. 213-234.

GENÇ, Reşat, 1999. "Atatürkçü Düşüncede Laiklik ve Din Anlayışı",Atatürk Düşüncesinde Din ve Laiklik, (Yayına Hazırlayanlar: Ethem Ruhi Fiğlalı-Taha Müftüoğlu-İdris Karakuş), Atatürk Araştırma Merkezi Yayını, Ankara, s.251258

..,2005. “1923’ten Günümüze Cumhuriyetin Türk Milletine Kazandırdıkları”, Beşinci Uluslararası Atatürk Kongresi 8-12 Aralık 2003-Ankara, (Hazırlayanlar: Mustafa Cöhce, Nilgün İnce, Neşe Çetinoğlu), Atatürk Araştırma Merkezi Yayını, Ankara, C.1. s. 97-104.

GİRITLİ, İsmet, 1991. Günümüzde Atatürkçülük, Der Yayınları, İstanbul.

GLASNECK, Johannes, 1976. Kemal Atatürk ve Çağdaş Türkiye, (Çeviren: Arif Gelen), Onur Yayınları, Ankara.

GOLOĞLU, Mahmut, 1973. Atatürk İlkeleri ve Bursa Nutku, Kalite Matbaası, Ankara.

GÖK, Dursun, AKANDERE, Osman, SÖNMEZ, Osman, SEMIZ, Yaşar, 2000. Atatürk İlkeleri ve İnkılâp Tarihi, Konya.

GÖKBERK, Macit, 1997. Aydınlanma Felsefesi, Devrimler ve Atatürk, Yenigün Haber Ajansı Yayını, (Cumhuriyet Gazetesi Armağanı), İstanbul.

GÜLER, Ali, 2007. Atatürk ve Cumhuriyet, TÜRKAR (Türk Metal Sendikası Araştırma Bürosu) Yayını, 2. Baskı, Ankara.

HABİLADEM, 2009. Mustafa Kemallerin Kitab1, (Yayına Hazırlayanlar: Haluk Kortel-Ali Cin), IQ kültür Sanat Yayıncılık, İstanbul.

HASANOVA, EsmeraldaYusif Kızı, 1988. “Türkiye'de Atatürkçülüğün Bir Çağdaşlaşma Modeli Gibi Yorumları Üzerine", Üçüncü Uluslararası Atatürk Sempozyumu 3-6 Ekim, 1995 - Gazi Mağusa Kuzey Kıbrıs Türk Cumhuriyeti, Atatürk Araştırma Merkezi Yayını, Ankara, C. 1, s. 383-391.
HATİPOĞLU, Vecihe, 1973. Cumhuriyetin Ellinci Y1lında Ölümsüz Atatürk ve Dil Devrimi, Türk Dil Kurumu Yayını, Ankara.

HUGHES, Preston, 1994. Atatürkçülük ve Türkiye'nin Demokratikleşme Süreci, (Çeviren: Rabia Süer), Milliyet Yayınları, 2. Bask1, İstanbul.

IRMAK, Sadi, 1981. Atatürk Devrimleri Tarihi, Yap1 ve Kredi Bankası Yayınları.

İPEK, Nedim, 2005. “Atatürk Döneminde Türkiye'nin Nüfus Siyaseti”, Beşinci Uluslararası Atatürk Kongresi 8-12 Aralık 2003-Ankara, (Hazırlayanlar: Mustafa Cöhce, Nilgün İnce, Neşe Çetinoğlu), Atatürk Araştırma Merkezi Yayını, Ankara, C.1. s. 173-190.

KARAL, Enver Ziya, 1945. Türkiye Cumhuriyeti Tarihi (1918-1944), Milli Eğitim Basımevi, İstanbul.

Milli Eğitim Basımevi, İstanbul. 1986.Atatürk’ten Düşünceler,

KARAOĞLU, Zeki Gürdal, 2017. "Cumhuriyet Dönemi Gösteri Sanatları ve Güzel Sanatlar", Cumhuriyet'in Kazanımları, (Editörler: Bülent Çukurova, Fevzi Çakmak), Dokuz Eylül Üniversitesi Yayınları, İzmir, s. 101-114.

KAYADİBİ, Fahri, 2005. "Atatürkçü Düşüncede Din ve Din Eğitimi”, Beşinci Uluslararası Atatürk Kongresi 8-12 Aralık 2003-Ankara, (Hazırlayanlar: Mustafa Cöhce, Nilgün İnce, Neşe Çetinoğlu), Atatürk Araştırma Merkezi Yayını, Ankara, C.2. s. 1037-1050.

KESKIN, Mustafa, 1998. “Atatürk'e Göre Milliyetçilik ve Bağımsızlık”, Üçüncü Uluslararası Atatürk Sempozyumu 3-6 Ekim, 1995 - Gazi Mağusa Kuzey Kıbrıs Türk Cumhuriyeti, Atatürk Araştırma Merkezi Yayını, Ankara, C. 1, s. 297-304.

KINROSS, Lord, 1994. Atatürk Bir Milletin Yeniden Doğuşu, (Çeviren: Necdet Sander), 12. Baskı, Altın Kitaplar Yayınevi, İstanbul.

KİLİ, Suna, 2008. Bir Çağdaşlaşma Modeli Atatürk Devrimi, Türkiye İș Bankası Kültür Yayınları, 11. Baskı, İstanbul.

KOCATÜRK, Utkan, 1999. Atatürk'ün Fikir ve Düşünceleri, Atatürk Araştırma Merkezi Yayını, Ankara.

KONGAR, Emre, 1981.Atatürk ve Devrim Kuramları, TISA Matbaası, Ankara.

1983. Devrim Tarihi ve Toplumbilim Açısından Atatürk, Remzi Kitabevi, İstanbul.

KURAN, Ercümend, 1981. Atatürkçülük Üzerine Denemeler, Kültür Bakanlığı Yayını, Ankara.

KURTCEPHE, İsrafil, 2005. "Çağdaşlaşma ve Laiklik", Beşinci Uluslararası Atatürk Kongresi 8-12 Aralık 2003Ankara, (Hazırlayanlar: Mustafa Cöhce, Nilgün İnce, Neşe Çetinoğlu), Atatürk Araştırma Merkezi Yayını, Ankara, C. 2, s. 939-949.

KÜRKÇÜOĞLU, Erol, 2000. “Atatürk, Milli Mücadele, Milli Devlet, Birlik-Beraberlik", Atatürk Konferansları (1999 Yılı-Yurtiçi), Atatürk Araştırma Merkezi Yayını, Ankara, s. 167-177.

MÜTERCİMLER, Erol, 2008, Aralık. Fikrimizin Rehberi Gazi Mustafa Kemal, Alfa Yayınları, 5. Baskı, İstanbul. 
NARTER, Meltem, 2004. Cumhuriyet Alg1S1 Siyasetin Gençlerin Kimliğindeki Yeri, Alfa Yayınları, 1. Baskı, İstanbul.

OLCAYTU, Turhan, 1998. Atatürk İlke ve İnk1lâpları, Anıtkabir Derneği Yayınları, Ankara.

ORAL, Atilla, 2006. Atatürk ve İktisadi Kalkınma "Türk Ticaret ve Sanayi Tarihi'nde Atatürk Dönemi”, Jotun Boya Sanayii ve Ticaret A.Ş. Yayını, 1. Baskı, İstanbul.

ÖZBEY, Mustafa, 2000. "Atatürkçü Düşünce Sisteminin Nitelikleri”, Atatürk Haftası Armağanı 10 Kasım 2000, ATASE Yayınları, Genelkurmay Basım Evi, Ankara, s. 273290.

ÖZBUDUN, Ergun, 1999. “Atatürk ve Laiklik”, Atatürk Düşüncesinde Din ve Laiklik, (Yayına Hazırlayanlar: Ethem Ruhi Fiğlal1-Taha Müftüoğlu-İdris Karakuş), Atatürk Araştırma Merkezi Yayını, Ankara, s.333-344.

ÖZÇELİK, İsmail, YAVUZ, Nuri, ALPARGU, Mehmet, 1991. Atatürk İlkeleri ve İnkılâp Tarihi, Ankara.

ÖZKES, İhsan, 2012. Atatürk, CHP ve Din.

ROGGENDORF, Nehir, 2008. Mehmetçik Taktı Adını “Efsunlu Kemal" 1881-1938, Sınır Ötesi Yayınları, İstanbul.

SANSAR, Fatih - TEMIZZER, Abidin, 2012. Türk İnkılâbı Tarihi, (Editör: Hasan Babacan), Öncü Yayınları, 2.Baskı, Ankara.

SARIKOYUNCU, Ali, İLGAZI, Abdullah, AKSANYAR, Necati, BIYIKLI, Mustafa, DEĞERLİ, Esra S., 2010. Atatürk İlkeleri ve İnkılâp Tarihi (Editör: Abdullah İlgazi), Savaş Yayınevi, 2. Baskı, Ankara.

SARINAY, Yusuf, 1990. Atatürk'ün Millet ve Milliyetçilik Anlayışı, Türk Kültürünü Araştırma Enstitüsü Yayını, Ankara.

SAYILI, Aydın, 2008. Atatürk ve Bilim, (Editör: Remzi Demir, Derleyen İnan Kalaycığulları), Atatürk Kültür Merkezi Yayını, Ankara.

SELEK, Sabahattin, 1973. Anadolu İhtilâli, Cem Yayınevi, İstanbul.

SOFUOĞLU, Süreyya, 1998. “Atatürk’te İnsan ve Doğa Sevgisi”, Üçüncü Uluslararası Atatürk Sempozyumu 3-6 Ekim, 1995 - Gazi Mağusa Kuzey Kıbrıs Türk Cumhuriyeti, Atatürk Araştırma Merkezi Yayını, Ankara, C. 2, s. 839-847.
ŞİMŞİR, Bilâl, 2006. Atatürk Dönemi-İncelemeler-, Atatürk Araştırma Merkezi Yayını, Ankara.

TANYOL, Cahit, 1981. Atatürk ve Halkçılık, Türkiye İş Bankası Yayınları, Ankara.

TOPDEMIR, Hüseyin Gazi, 2010. "Takıyyüddin erRâsıd”, Türkiye Diyanet Vakfı İslâm Ansiklopedisi, İstanbul, C.39, s. 454-456.

TURAL, Mehmet Akif, 2000. “Atatürk İnkılâpları İle Yaşanan Sosyal Değişme”, Atatürk 4.Uluslararası Kongresi 25-29 Ekim 1999, Türkistan-Kazakistan, Atatürk Araştırma Merkezi Yayını, Ankara, C. 2, s. 1247-1254.

TURAN, Refik, SAFRAN, Mustafa, HAYTA, Necdet, ÇAKMAK, M.Ali, DÖNMEZ, Cengiz, ŞAHINN, Muhammet, 2011. Atatürk İlkeleri ve İnkılâp Tarihi, Okutman Yayıncılık, Ankara.

TURHAN, Mümtaz, 1965. Atatürk İlkeleri ve Kalkınma Sosyal Psikoloji Bakımından Bir Tetkik, İstanbul.

TÜNAY, Bekir, 2004. "Atatürk ve Millî Birlik", Atatürkçü Düşünce El Kitabı I, Atatürk Araştırma Merkezi Yayını, Ankara, s.259-269.

TÜRKDOĞAN, Orhan, 2005. Kemalist Sistem ve Sosyolojik Yapısı, 1. Baskı, İstanbul.

Türkiye Cumhuriyeti'nin Temel İlkelerinden Laiklik (Panel), 1995. Atatürk Kültür, Dil ve Tarih Yüksek Kurumu Atatürk Araştırma Merkezi Yayını, 2. Baskı, Türk Tarih Kurumu Basımevi, Ankara.

ÜLKEN, Yüksel, 1981. Atatürk ve İktisat, Türkiye İş Bankası Yayını, Ankara.

VARDI, Rahmi, 2006. Atatürk'ün Manevi Dünyası, Şeyh Yahya Efendi Kültür ve Araştırma Vakfı Yayınları, İstanbul.

VILLALTA, Jorge Blanco, 2000. Atatürk, (Çeviren: Fatih Özsü), T.C. Kültür Bakanlığı Yayını, 2. Baskı, Ankara.

YAVRU, Mehmet, 1981. Atatürkçülük ve İlkeleri, Arı Basımevi, 3. Baskı, Konya.

YILMAZ, Mustafa, ERTAN, Temuçin Faik, SARINAY, Yusuf, DAĞISTAN, Adil, KILINÇKAYA, M. Derviş, SEZER, Ayten, AYTEPE, Oğuz, AKTAŞ, Ayşe, 1998. Atatürk ve Türkiye Cumhuriyeti Tarihi, Siyasal Kitabevi, Ankara. 